\title{
Induce Systemic Resistance against Root Rot and Wilt Diseases in Fodder Beet (Beta vulgaris L. var. rapacea Koch.) by Using Potassium Salts
} Montaser F Abdel-Monaim*, Marwa AM Atwa and Kadry M Morsy

Plant Pathology Research Institute, Agriculture Research Center, Giza 12619, Egypt

\begin{abstract}
Rhizoctonia solani, Fusarium solani, F. oxysporum F. equiseti and F. semitectum were found to be associated with root rot and wilt symptoms of fodder beet plants collected from different fields in New Valley governorate, Egypt. All the obtained isolates were able to attack fodder beet plants (cv. Starmon) causing damping-off and root rot/wilt diseases. $R$. solani isolate FB1, F. solani isolate FB7 and F. oxysporum isolate FB11 were the more virulent ones in the pathogenicity tests. The efficacy of 4 different potassium salts for controlling damping-off, root rot and wilt diseases in fodder beet were evaluated in vitro and in vivo.

In vitro studies, all the tested potassium salts were significantly suppressed growth of the pathogenic fungi at different concentrations. $\mathrm{KHCO}_{3}$ showed superior higher inhibitory effect on redial growth of the tested pathogenic fungi especially at higher concentration $(20 \mathrm{mM})$.

Under green house and field conditions, all potassium salts significantly reduced damping-off and root rot/wilt severity and increased survival of plants. The reduction in damping-off and root rot/wilt increased with increasing of potassium salts concentration except potassium sulfate $\left(\mathrm{K}_{2} \mathrm{SO}_{4}\right)$, while concentration 10 mM was more effective for reducing damping-off and root rot/wilt severity than $20 \mathrm{mM}$. $\mathrm{K}_{2} \mathrm{SiO}_{3}$ followed by $\mathrm{K}_{2} \mathrm{HPO}_{4}$ recorded highly protection against damping-off and root rot/wilt severity more than the other tested potassium salts. Under field conditions, all these potassium salts at different concentrations significantly submitted to various growth and yield parameters viz. root length, root diameters, fresh and dry weights compared with control during growing seasons 2013-14 and 2014-15. While, \% dry maters was no significant in both growing seasons. The applied treatment $\mathrm{K}_{2} \mathrm{SiO}_{3}$ achieved the highest increase in all the mentioned parameters over the other entire three potassium salts during both growing seasons.

In physiological studies, activity of defense-related enzymes, including peroxidase (PO), polyphenol oxidase (PPO), phenylalanine ammonia lyase (PAL), and tyrosine ammonia lyase ( $T A L$ ) and total phenols content were increased in inoculated plants with $R$. solani, F. solani, and $F$. oxysporum individually and treated with potassium salts compared with untreated plants. $\mathrm{K}_{2} \mathrm{SiO}_{3}$ at $20 \mathrm{mM}$ showed the highest level of all oxidative enzymes activity and total phenols content followed by $\mathrm{K}_{2} \mathrm{HPO}_{4}$ and $\mathrm{K}_{2} \mathrm{SO}_{4}$ at $20 \mathrm{mM}$. Whereas, the least enzymes activity was recorded with $\mathrm{KHCO}_{3}$ at $10 \mathrm{mM}$. These results suggested that these chemicals may be play an important role in controlling the fodder beet damping-off, root rot and wilt diseases; through they have induction of systemic resistance in fodder beet plants.
\end{abstract}

Keywords: Fodder beet; Root rot and wilt; Potassium salts; Induced resistance

\section{Introduction}

Fodder beet (Beta vulgaris L. var. rapacea Koch.) offers a higher yield potential than any other "arable" fodder crop. The roots have an excellent feed quality and they are very palatable to ruminant stock. The leaf can be utilized if required to boost the total fodder output even further. Fodder beet when grown under suitable conditions, can produce almost $20 \mathrm{t} \mathrm{ha}^{-1}$ dry matter yield compared with $13 \pm 15 \mathrm{t} \mathrm{DM} /$ $\mathrm{ha}^{-1}$ from four harvests of grass. Approximately $75 \%$ of fodder beet dry matter is in the root component [1]. Including fodder beet in diet of cattle increases intake of dry matter that is quantitative and qualitative factors affecting intake of the basal diet $[2,3]$.

Plant diseases caused by soil-borne plant pathogens considered the major problems in agricultural production throughout the world, reducing yield and quality of crops. Plant pathogens have caused an almost $20 \%$ reduction in the principal food and cash crops worldwide [4]. Root rot and wilt caused by soil-borne pathogenic fungi is one of the most serious diseases affected several cultivated plants in worldwide. It results in poor production, poor quality, poor milling returns and reduced agriculture income. This has a negative impact on the livelihood of farmers [5]. Fungal disease control is achieved through the use of fungicides which is hazardous and toxic to both people and domestic animals and leads to environmental pollution [6]. Therefore, a more balanced, cost effective and eco-friendly approach must be implemented and adopted farmers. In order to overcome such hazardous control strategies, scientists, researchers from all over the world paid more attention towards the development of alternative methods which are, by definition, safe in the environment, non-toxic to humans and animals and are rapidly biodegradable.

*Corresponding author: Montaser F Abdel-Monaim, Plant Pathology Research Institute, Agriculture Research Center, Giza 12619, Egypt, Tel: +20927936364 E-mail: fowzy_2008@yahoo.com

Received November 03, 2015; Accepted November 16, 2015; Published November 20, 2015

Citation: Abdel-Monaim MF, Atwa MAM, Morsy KM (2015) Induce Systemic Resistance against Root Rot and Wilt Diseases in Fodder Beet (Beta vulgaris $\mathrm{L}$. var. rapacea Koch.) by Using Potassium Salts. J Plant Pathol Microbiol 6: 315 doi:10.4172/2157-7471.1000315

Copyright: @ 2015 Abdel-Monaim MF, et al. This is an open-access article distributed under the terms of the Creative Commons Attribution License, which permits unrestricted use, distribution, and reproduction in any medium, provided the original author and source are credited. 
The present research focuses on finding compounds that are safe to humans and the environment, viz. potassium salts are recorded by several investigators to have antimicrobial inhibitor effect as well as they play important role to induce plant resistance against dampingoff, root rot and wilt diseases of fodder beet either in vitro or in vivo as well as its effective on plant growth and yield components in field.

\section{Materials and Methods}

\section{Seeds and growth of plants}

Fodder beet (Beta vulgaris L. var. rapacea Koch.) cultivar Starmon used in this study was obtained from the Forage Research Dep., Field Crops Research Institute, Agricultural Research Center, Giza, Egypt. Seeds were planted in plastic pots $30 \mathrm{~cm}$ diameter $(2.4 \mathrm{~kg}$ soil), filled with a pasteurized mixture of soil and sand $(4: 1 \mathrm{w} / \mathrm{w})$. Five seeds were sown in each pot and these pots were irrigated every three days.

\section{Fungal isolation and pathogenicity tests}

Samples of fodder beet plants showing root rot and wilt symptoms were collected from different farms of New Valley governorates. All samples were thoroughly washed with tap water several times, cut in small pieces and surface sterilized for $2 \mathrm{~min}$ in $2 \%$ sodium hypochlorite solution, then rinsed several times in sterilized distilled water and dried between sterilized filter papers. The surface sterilized samples were plated onto potato dextrose agar (PDA) medium and incubated at $25 \pm 1^{\circ} \mathrm{C}$. After 3-7 days incubation, the developed fungal colonies were purified by hyphal tip and/or single spore isolation techniques. The obtained fungal isolates were identified according to their cultural and microscopical characters as described by Booth [7] and Barnett and Hunter [8]. Subcultures of the obtained isolates were then kept on PDA slants and stored at $5^{\circ} \mathrm{C}$ for further studies.

Inoculum of the obtained isolates of soil borne pathogens was prepared on autoclaved barley medium ( $75 \mathrm{~g}$ washed dried barley grains, $100 \mathrm{~g}$ washed dried coarse sand and $75 \mathrm{ml}$ tap water) in 500 $\mathrm{ml}$ glass bottles. Each bottle was inoculated with five discs $(0.7 \mathrm{~cm}$ in diameter) of 4-day-old cultures of each isolates. Bottles were incubated at $25 \pm 1^{\circ} \mathrm{C}$ for 15 days [9]. For each isolate, the contents of 20 bottles were thoroughly mixed in a plastic container and used as a source of inoculum. Soil and pots were sterilized with a 5\% formalin solution for $15 \mathrm{~min}$. Soil was covered with a polyethylene sheet for 7 days to retain the gas and left to dry for 2 weeks until all traces of formaldehyde disappeared. Pathogen inocula were added to the potted soil at a rate of $3 \%(\mathrm{w} / \mathrm{w})$ and mixed thoroughly with the soil one week before planting. Three pots were used as replicates for each isolate (1-16) as well as control (uninfested soil). Fodder beet seeds of cv. Starmon were surface sterilized using 1\% sodium hypochlorite for $2 \mathrm{~min}$, rinsed in distilled water several times and sown in pots at rate 5 seeds pot ${ }^{-1}$. These pots were irrigated every three days.

\section{Assessment of disease severity}

Percentage of damping-off was recorded after 35 days after planting. While severity of root rot and was determined 90 days after planting according to Abdou et al. [10] using a rating scale of $0-5$ on the basis of root the discoloration or leaf yellowing as follows, $0=$ neither root discoloration nor leaf yellowing, $1=1-25 \%$ root discoloration or one leaf yellowed, $2=26-50 \%$ root discoloration or more than one leaf yellowed, $3=51-75 \%$ root discoloration plus one leaf wilted, $4=$ up to $76 \%$ root discoloration or more than one leaf wilted, and $5=$ completely dead plants. For each replicate a disease severity index (DS\%) similar to that described by Liu et al. [11] was calculated as follows:

$$
D S I=\frac{\Sigma d}{d \max \times n} \times 100
$$

Whereas: $d$ is the disease rating possible, $d$ max is the maximum disease rating and $\mathrm{n}$ is the total number of plants examined in each replicate.

\section{In vitro antifungal activity}

The inhibitory effect of potassium salts viz. potassium phosphate dibasic $\left(\mathrm{K}_{2} \mathrm{HPO}_{4}\right)$, potassium bicarbonate $\left(\mathrm{KHCO}_{3}\right)$, potassium sulfate $\left(\mathrm{K}_{2} \mathrm{SO}_{4}\right)$, potassium silicate $\left(\mathrm{K}_{2} \mathrm{SiO}_{3}\right)$ at different concentrations 5,10 and $20 \mathrm{mM}$ (listed in Table 1) on the linear growth of Rhizoctonia solani, Fusarium solani and F. oxysporum, the fodder beet root rot and wilt pathogens, was evaluated. Tested solutions were added to conical flasks containing sterilized PDA medium before solidifying to obtain the proposed concentrations and shacked gently, then dispensed into sterilized Petri dishes (9-cm diameter). Petri dishes were individually inoculated with equal disks (7-mm-diam.), taken from 7-day-old cultures of tested fungi. The Petri dishes containing the PDA medium inoculated with the tested pathogens alone served as control. All plates were incubated at $25 \pm 1^{\circ} \mathrm{C}$. Each treatment was represented by 3 plates as replicates. Linear growth of tested fungi was measured when the control plates (medium free of potassium salts) reached full growth and the average growth diameter was calculated. Mycelial growth inhibition was calculated by using the formula:

\section{Mycelial growth inhibition (\%)=100 (C-T/C)}

Where $\mathrm{C}=$ growth in control and $\mathrm{T}=$ growth in treatment.

\section{Evaluation effect of potassium salts on damping-off, root rot and wilt diseases under greenhouse conditions}

The fungal inoculum of $R$. solani (isolate FB1), F. solani (isolate FB7) and F. oxysporum (isolate FB 11) were prepared as described before in pathogenicity test. Plastic pots $(30 \mathrm{~cm}$ diameter) were packed with sterilized sandy clay soil infested with fungal inocula at the rate $3 \%(\mathrm{w} / \mathrm{w})$, seven days before planting. Fodder beet cv. disinfested seeds were soaked in the solution of each potassium salts (Table 1) for $12 \mathrm{hr}$. [12], then sown in infested pots at rate 5 seeds pot $^{-1}$. Also, in control treatment, fodder beet seeds soaked in water for the same time and seeding in infested soil with the pathogen at the same rate. Three pots were used per treatment as a replicates. Percentages of damping-off, root rot and wilt severity were recorded after 35 and 90 days from planting, respectively.

\section{Evaluation effect of potassium salts on damping-off, root rot and wilt diseases and under greenhouse conditions}

This experimental, factorial block design experiment was conducted at sowing date of 1 st November of two successive growing seasons 2013/14 and 2014/15 in a field naturally infected with the causal organisms of root rot and wilt diseases of fodder beet located at the experimental farm of Kharga Agric. Station, New Valley Governorate. The main plots were potassium salts tested, sub plots were concentrations. Healthy fodder beet seeds were soaked in the solutions of the potassium salts for $12 \mathrm{hrs}$.

\begin{tabular}{|c|c|c|c|}
\hline Materials & $\begin{array}{c}\text { Chemical } \\
\text { Composition }\end{array}$ & $\begin{array}{c}\text { Molecular } \\
\text { Weight }\end{array}$ & $\begin{array}{c}\text { Used } \\
\text { Concentration }\end{array}$ \\
\hline Potassium phosphate dibasic & $\mathrm{K}_{2} \mathrm{HPO}_{4}$ & $174.18 \mathrm{~g} / \mathrm{mol}$ & $5,10,20 \mathrm{mM}$ \\
\hline Potassium bicabonate & $\mathrm{KHCO}_{3}$ & $100.12 \mathrm{~g} / \mathrm{mol}$ & $5,10,20 \mathrm{mM}$ \\
\hline Potassium sulfate & $\mathrm{K}_{2} \mathrm{SO}_{4}$ & $174.26 \mathrm{~g} / \mathrm{mol}$ & $5,10,20 \mathrm{mM}$ \\
\hline Potassium silicate & $\mathrm{K}_{2} \mathrm{SiO}_{3}$ & $154.28 \mathrm{~g} / \mathrm{mol}$ & $5,10,20 \mathrm{mM}$ \\
\hline
\end{tabular}

Table 1: Chemical formula of potassium salts. 
Citation: Abdel-Monaim MF, Atwa MAM, Morsy KM (2015) Induce Systemic Resistance against Root Rot and Wilt Diseases in Fodder Beet (Beta vulgaris L. var. rapacea Koch.) by Using Potassium Salts. J Plant Pathol Microbiol 6: 315. doi:10.4172/2157-7471.1000315

[12]. A plot was $3 \times 3.5 \mathrm{~m}$ with five rows; $50 \mathrm{~cm}$ row spacing, seeds were sown in hills ( 2 seeds hill 1 and $25 \mathrm{~cm}$ apart). In the control treatment, fodder beet seeds were soaked in water for the same time and sown with the same method. Fertilizers application at the rate of recommended doses. The crop was irrigated at 12-15 days intervals. Hand thinning to one plant per hill after 5 weeks from planting [3]. Percentages of damping-off and root rot/wilt disease index were calculated after 35 and 120 days from planting, respectively. At harvesting, 10 plants from the central ridges were pulled up to determine the following growth traits and forage yield.

1. Root length $(\mathrm{cm})=$ distance between the beginning of the root to an end.

2. Root diameter $(\mathrm{cm})=$ Circumference of circle when the maximum width of root divided on 2.14 .

3. Fresh and dry weights of roots (ton/fed.).

4. Dry maters $(\%)=$ Dry weight of roots/Fresh weight of roots $\times$ 100

\section{Biochemical changes associated with induced resistance}

Activities of peroxidase (PO), polyphenol oxidase (PPO), phenylalanine ammonia lyase (PAL) and tyrosine ammonia lyase (TAL) and total phenols content was studied in tissue extracts of fodder beet plants surviving treatment with $\mathrm{K}_{2} \mathrm{HPO}_{4}, \mathrm{KHCO}_{3}$ and $\mathrm{K}_{2} \mathrm{SiO}_{3}$ at $20 \mathrm{mM}$ and $\mathrm{K}_{2} \mathrm{SO}_{4}$ at $10 \mathrm{mM}$, as well as in untreated seeds. All treatments were grown in soil infested with R. solani, F. solani, F. oxysporum as individually. One gram of plant tissue was homogenized in $10 \mathrm{~mL}$ of ice-cold $50 \mathrm{mM}$ potassium phosphate buffer $(\mathrm{pH} 6.8)$ containing $1 \mathrm{M} \mathrm{NaCl}, 1 \%$ polyvinylpyrrolidone, $1 \mathrm{mM}$ EDTA, and $10 \mathrm{mM} \beta$-mercaptoethanol [13]. After filtration through cheesecloth, the homogenates were centrifuged at $8,000 \mathrm{rpm}$ at $4^{\circ} \mathrm{C}$ for $25 \mathrm{~min}$. The supernatants (crude enzyme extract) were stored at $-20^{\circ} \mathrm{C}$ or immediately used for determination of PO, PPO, PAL and TAL activities and total protein. For the determination of enzyme activities, each treatment consisted in four replicates (three plants/ replicate) and two spectrophotometric readings were taken per replicate using a Milton Roy 1201 Spectrophotometer (PEMED', Denver, CO, USA). The bioassay experiments were repeated twice.

\section{PO activity}

PO activity was determined directly using a spectrophotometrical method [14] using guaiacol as common substrate. The reaction mixture consisted of $0.2 \mathrm{~mL}$ crude enzyme extract and $1.40 \mathrm{~mL}$ of a solution containing guaiacol, hydrogen peroxide $\left(\mathrm{H}_{2} \mathrm{O}_{2}\right)$ and sodium phosphate buffer $\left(0.2 \mathrm{~mL} 1 \%\right.$ guaiacol $+0.2 \mathrm{~mL} 1 \% \mathrm{H}_{2} \mathrm{O}_{2}+1 \mathrm{~mL} 10 \mathrm{mM}$ potassium phosphate buffer). The mixture was incubated at $25^{\circ} \mathrm{C}$ for $5 \mathrm{~min}$ and the initial rate of increase in absorbance was measured over $1 \mathrm{~min}$ at $470 \mathrm{~nm}$. Activity was expressed as units of $\mathrm{PO} / \mathrm{mg}$ protein [15].

\section{PPO activity}

The activity of PPO was determined by adding $50 \mu \mathrm{L}$ of the crude extract to $3 \mathrm{~mL}$ of a solution containing $100 \mathrm{mM}$ potassium phosphate buffer, pH 6.5 and $25 \mathrm{mM}$ pyrocatechol. The increase of absorbance at $410 \mathrm{~nm}$ during $10 \mathrm{~min}$ at $30^{\circ} \mathrm{C}$, was measured [16]. One PPO unit was expressed as the variation of absorbance at $410 \mathrm{~nm}$ per mg soluble protein per min.

\section{PAL activity}

PAL activity was determined following a previously-described direct spectrophotometric method [17]. Two hundred microlitres of the crude enzyme extract previously dialyzed overnight with $100 \mathrm{mM}$ Tris- $\mathrm{HCl}$ buffer, $\mathrm{pH} 8.8$, were mixed to obtain a solution containing $200 \mu \mathrm{L} 40 \mathrm{mM}$ phenylalanine, $20 \mu \mathrm{L} 50 \mathrm{mM} \beta$-mercaptoethanol, and $480 \mu \mathrm{L} 100 \mathrm{mM}$ Tris- $\mathrm{HCl}$ buffer, $\mathrm{pH} 8.8$. After incubation at $30^{\circ} \mathrm{C}$ for 1 $\mathrm{hr}$, the reaction stopped by adding $100 \mu \mathrm{L} 6 \mathrm{~N} \mathrm{HCl}$. Absorbance at 290 $\mathrm{nm}$ was measured and the amount of trans-cinnamic acid formed was evaluated by comparison with a standard curve $(0.1 \sim 2 \mathrm{mg} / \mathrm{mL}$ trans cinnamic acid) and expressed as units of $\mathrm{PAL} / \mathrm{min} / \mathrm{mg}$ protein.

\section{TAL activity}

TAL activity was determined using the same method used for PAL except L-tyrosine was used instead of phenylalanine.

\section{Protein concentration}

Total protein content of the samples was quantified according to the method described by Bradford [18].

\section{Determination of phenolic compounds}

To assess phenolic content, $1 \mathrm{~g}$ fresh plant sample was homogenized in $10 \mathrm{~mL} 80 \%$ methanol and agitated for $15 \mathrm{~min}$ at $70^{\circ} \mathrm{C}$. One milliliter of the extract was added to $5 \mathrm{~mL}$ of distilled water and $250 \mu \mathrm{L}$ of 1 $\mathrm{N}$ Folin-Ciocalteau reagent and the solution was kept at $25^{\circ} \mathrm{C}$. The absorbance was measured with a spectrophotometer at $725 \mathrm{~nm}$. Catechol was used as a standard. The amount of phenolic content was expressed as phenol equivalents in $\mathrm{mg} / \mathrm{g}$ fresh tissue [19].

\section{Statistical analysis}

All experiments were performed twice. Analyses of variance were carried out using MSTAT-C program version 2.10 [20] (1991). Least significant difference (LSD) was employed to test for significant difference between treatments at $\mathrm{P} \leq 0.05$ [21].

\section{Results}

\section{Isolation, purification and identification of the cauasl fungi}

Isolation trials from naturally rotted roots of fodder beet plants coallected from many field grown in New Valley governorate yeilded sexteen fungal isolates. The obtained isoltes were purified using single spore method and/or hyphal tip technique. The purified fungi were identified as Rhizoctonia solani (5 isolates), F. solani (4 isolates), Fusarium equiseti (1 isolates), F. oxysporum (4 isolates), F. semitectum ( 2 isolates). These fungi were maintained as pure cultures on ager slants kept in refrigerator at $5{ }^{\circ} \mathrm{C}$ until using in further studies.

\section{Pathogenicity tests}

Pathogenicity tests of the isolated fungi (Figure 1) reveal that all the isolates were pathogenic to fodder beet plants cv. Starmon with deferent degrees caused damping-off and root rot/wilt symptoms. In this respect $R$. solani isolate FB1 caused the highest damping-off (60\%) followed by $R$. solani isolate FB2 and F. solani isolate FB7 (53.33\%) while F. equiseti isolate FB10 caused the lowest damping-off (6.67\%). On the other hand, F. oxysporum isolate FB11 recorded the highest severity of wilt disease $(60.33 \%)$ followed by $R$. solani isolate FB3 (45.36\% root rot). Generally, R. solani isolate FB1, F. solani isolate FB7 and $F$. oxysporum $\mathrm{FB} 11$ were the highest pathogenic fungi isolated from fodder beet while recorded the lowest survival plants $(9.65,14.11$ and $13 \%$, respectively) since these isolates were used in following studies in vitro and/or in vivo. While, both F. semitectum isolates showed the lowest damping-off and root rot severity therefore they were neglected from the following studies. 
Citation: Abdel-Monaim MF, Atwa MAM, Morsy KM (2015) Induce Systemic Resistance against Root Rot and Wilt Diseases in Fodder Beet (Beta vulgaris L. var. rapacea Koch.) by Using Potassium Salts. J Plant Pathol Microbiol 6: 315. doi:10.4172/2157-7471.1000315

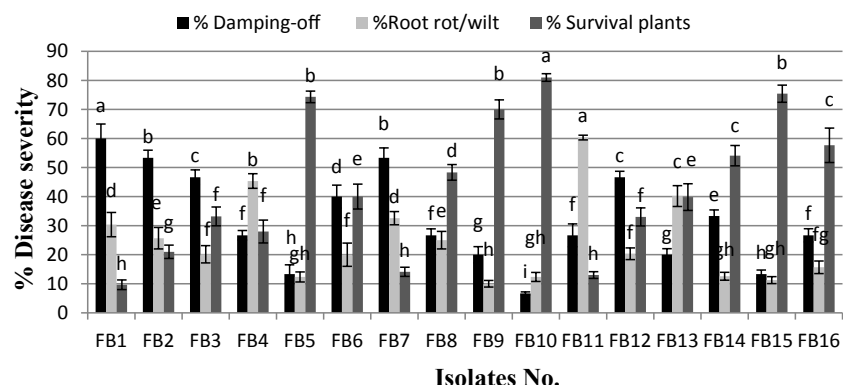

Figure 1: Pathogenicity tests of soil borne fungi isolated from fodder beet roots under the greenhouse conditions. Mean \pm SDs per isolate are shown. Different letters indicate significant differences among treatments within the same color column according to least significant difference test $(P \leq 0.05)$ Percentages of damping-off were recorded 35 days after planting, while root rot/wilt disease severity was determined 90 days after planting.

\begin{tabular}{|c|c|c|c|c|}
\hline \multirow[b]{2}{*}{ Potassium salts } & \multirow[b]{2}{*}{ Concen. (mM) } & \multicolumn{3}{|c|}{$\%$ Inhibition } \\
\hline & & $\begin{array}{c}\text { Rhizoctonia } \\
\text { solani }\end{array}$ & $\begin{array}{c}\text { Fusarium } \\
\text { solani }\end{array}$ & $\begin{array}{c}F . \\
\text { oxysporum }\end{array}$ \\
\hline \multirow{4}{*}{$\mathrm{K}_{2} \mathrm{HPO}_{4}$} & 5 & 25.36 & 33.26 & 36.25 \\
\hline & 10 & 32.25 & 41.25 & 44.14 \\
\hline & 20 & 36.47 & 46.25 & 50.14 \\
\hline & Mean & 31.36 & 40.25 & 43.51 \\
\hline \multirow{4}{*}{$\mathrm{KHCO}_{3}$} & 5 & 32.25 & 36.35 & 41.29 \\
\hline & 10 & 41.25 & 46.54 & 55.14 \\
\hline & 20 & 50.12 & 52.36 & 62.14 \\
\hline & Mean & 41.21 & 45.08 & 52.86 \\
\hline \multirow{4}{*}{$\mathrm{K}_{2} \mathrm{SO}_{4}$} & 5 & 32.36 & 35.14 & 36.36 \\
\hline & 10 & 38.53 & 42.15 & 47.24 \\
\hline & 20 & 44.23 & 47.05 & 58.71 \\
\hline & Mean & 38.37 & 41.45 & 47.44 \\
\hline \multirow{4}{*}{$\mathrm{K}_{2} \mathrm{SiO}_{3}$} & 5 & 31.25 & 36.96 & 38.96 \\
\hline & 10 & 36.96 & 44.72 & 48.75 \\
\hline & 20 & 43.59 & 50.21 & 58.96 \\
\hline & Mean & 37.27 & 43.96 & 48.89 \\
\hline \multicolumn{5}{|l|}{ LSD at 0.05 for: } \\
\hline \multicolumn{2}{|l|}{ Potassium salts $(A)=$} & \multicolumn{3}{|c|}{2.59} \\
\hline \multicolumn{2}{|l|}{ Concentrations $(B)=$} & \multicolumn{3}{|c|}{3.47} \\
\hline \multicolumn{2}{|c|}{ Pathogenic fungi $(C)=$} & \multicolumn{3}{|c|}{2.25} \\
\hline \multicolumn{2}{|c|}{ Interaction $(A \times B \times C)=$} & \multicolumn{3}{|c|}{7.59} \\
\hline
\end{tabular}

Table 2: Effect of different concentrations of potassium salts on mycelial growth of $R$. solani, F. solani and F. oxysporum in vitro.

\section{Effect of potassium salts on the redial growth of pathogenic fungi}

Data in Table 2 show that all concentrations of the tested potassium salts resulted in a significantly suppressed redial growth of the tested pathogenic fungi (R. solani, F. solani, F. oxysporum) compared with the check treatment (control). The growth inhibition (\%) of the tested fungi was increased with the increasing of concentrations of all tested substances. $\mathrm{KHCO}_{3}$ showed superior higher inhibitory effect on redial growth of the tested pathogenic fungi especially at higher concentration $(20 \mathrm{mM})$. In this regard, the recorded reduction in the growth of R. solani, F. solani, F. oxysporum was 50.12, 52.36 and $62.14 \%$, respectively. On the other hand, the growth of $F$. oxysporum followed by F. solani showed the most affective then R. solani.
Effect of potassium salts of damping-off and root rot/wilt under greenhouse conditions

Fodder beet seeds soaking in tested potassium salts reduced significantly damping-off and root rot/wilt caused by R. solani, F. solani and F. oxysporum compared with control (Table 3). The reduction in damping-off and root rot/wilt increased with increasing of potassium salts concentration except $\mathrm{K}_{2} \mathrm{SO}_{4}$ while concentration $10 \mathrm{mM}$ was more effective for reducing damping-off and root rot/wilt severity than 20 $\mathrm{mM} . \mathrm{K}_{2} \mathrm{SiO}_{3}$ followed by potassium phosphate dibasic $\left(\mathrm{K}_{2} \mathrm{HPO}_{4}\right)$ recorded highly protection against damping-off and root rot/wilt severity more than the other tested potassium salts. $\mathrm{K}_{2} \mathrm{SiO}_{3}$ and $\mathrm{K}_{2} \mathrm{HPO}_{4}$ at $20 \mathrm{mM}$ recorded the highest reduction of damping-off caused by R. solani $(6.67,13.33 \%)$, F. solani $(6.67,6.67)$ and F. oxysporum $(6.67$ and $13.33 \%$ ) compared with $66.67,40,26.67 \%$ in control, respectively. Similar results were obtained with root rot /wilt incidence caused by $R$. solani and F. solani and F. oxysporum while, fodder seeds treated with $\mathrm{K}_{2} \mathrm{SiO}_{3}$ and $\mathrm{K}_{2} \mathrm{HPO}_{4}$ at $20 \mathrm{mM}$ reduced root rot/wilt severity from 22.14 , 33.29 and $56.39 \%$ in control to $4.59,5.67,10.58$ in case of $\mathrm{K}_{2} \mathrm{SiO}_{3}$ and $6.36,8.52$ and 6.54 in case of $\mathrm{K}_{2} \mathrm{HPO}_{4}$, respectively.

\section{Effect of potassium salts of damping-off and root rot/wilt under field conditions}

Data present in Table 4 show that all tested concentrations of potassium salts significantly reduced damping-off and root rot/wilt diseases under nutrition infection in field during growing seasons (2013-14 and 2014-15) compared with control. The reduction in damping-off and root rot/wilt increased with increasing of potassium salts concentration except $\mathrm{K}_{2} \mathrm{SO}_{4}$ while concentration $10 \mathrm{mM}$ was more effective for reducing damping-off and root rot/wilts severity than 20

\begin{tabular}{|c|c|c|c|c|c|c|c|}
\hline \multirow[b]{2}{*}{$\begin{array}{l}\text { Potassium } \\
\text { salts }\end{array}$} & \multirow[b]{2}{*}{$\begin{array}{c}\text { Concen. } \\
\text { (g/L) }\end{array}$} & \multicolumn{2}{|c|}{ Rhizoctonia solani } & \multicolumn{2}{|c|}{ Fusarium solani } & \multicolumn{2}{|c|}{ F. oxysporum } \\
\hline & & $\begin{array}{c}\% \\
\text { Damping- } \\
\text { off }\end{array}$ & $\begin{array}{c}\% \\
\text { Root rot }\end{array}$ & $\begin{array}{c}\% \\
\text { Damping- } \\
\text { off }\end{array}$ & $\begin{array}{c}\% \\
\text { Root rot }\end{array}$ & $\begin{array}{c}\% \\
\text { Damping- } \\
\text { off }\end{array}$ & $\begin{array}{c}\% \\
\text { Wilt }\end{array}$ \\
\hline \multirow{4}{*}{$\mathrm{K}_{2} \mathrm{HPO}_{4}$} & 5 & 33.33 & 15.67 & 20.00 & 13.26 & 13.67 & 13.67 \\
\hline & 10 & 20.00 & 10.34 & 13.33 & 10.24 & 13.67 & 8.36 \\
\hline & 20 & 13.33 & 6.36 & 6.67 & 8.52 & 13.67 & 6.54 \\
\hline & Mean & 22.22 & 10.79 & 13.33 & 10.67 & 13.67 & 9.52 \\
\hline \multirow{4}{*}{$\mathrm{KHCO}_{3}$} & 5 & 40.00 & 18.36 & 33.33 & 30.24 & 20.00 & 42.36 \\
\hline & 10 & 26.67 & 12.36 & 20.00 & 22.42 & 20.00 & 33.14 \\
\hline & 20 & 20.00 & 8.45 & 13.33 & 19.36 & 13.67 & 25.42 \\
\hline & Mean & 28.89 & 13.06 & 22.22 & 24.01 & 17.89 & 33.64 \\
\hline \multirow{4}{*}{$\mathrm{K}_{2} \mathrm{SO}_{4}$} & 5 & 40.00 & 19.36 & 33.33 & 25.67 & 20.00 & 44.67 \\
\hline & 10 & 20.00 & 10.36 & 26.67 & 13.37 & 13.67 & 25.34 \\
\hline & 20 & 26.67 & 15.35 & 33.33 & 19.49 & 20.00 & 35.52 \\
\hline & Mean & 28.89 & 15.02 & 31.11 & 19.51 & 17.89 & 35.18 \\
\hline \multirow{4}{*}{$\mathrm{K}_{2} \mathrm{SiO}_{3}$} & 5 & 26.67 & 10.36 & 13.33 & 10.24 & 13.67 & 20.23 \\
\hline & 10 & 20.00 & 7.24 & 13.33 & 7.69 & 13.67 & 13.25 \\
\hline & 20 & 6.67 & 4.59 & 6.67 & 5.67 & 6.67 & 10.58 \\
\hline & Mean & 17.78 & 7.40 & 11.11 & 7.87 & 9.00 & 14.69 \\
\hline \multicolumn{2}{|c|}{ Control } & 66.67 & 22.14 & 40.00 & 33.29 & 26.67 & 56.39 \\
\hline \multicolumn{2}{|c|}{ LSD at 0.05 for: } & \multicolumn{3}{|c|}{ Damping-off } & \multicolumn{3}{|c|}{ Root rot/wilt } \\
\hline \multicolumn{2}{|c|}{ Potassium salts $(A)=$} & \multicolumn{3}{|c|}{3.29} & \multicolumn{3}{|c|}{2.87} \\
\hline \multicolumn{2}{|c|}{ Concentrations $(B)=$} & \multicolumn{3}{|c|}{4.85} & \multicolumn{3}{|c|}{4.80} \\
\hline \multicolumn{2}{|c|}{$\begin{array}{l}\text { Pathogenic fungi } \\
\text { (C)= }\end{array}$} & \multicolumn{3}{|c|}{3.47} & \multicolumn{3}{|c|}{3.54} \\
\hline \multicolumn{2}{|c|}{ Interaction $(A \times B \times C)=$} & \multicolumn{3}{|c|}{10.48} & \multicolumn{3}{|c|}{8.76} \\
\hline
\end{tabular}

Table 3: Effect of fodder beet seeds treatment with potassium salts on dampingoff, root rot/wilt diseases under greenhouse conditions. 
Citation: Abdel-Monaim MF, Atwa MAM, Morsy KM (2015) Induce Systemic Resistance against Root Rot and Wilt Diseases in Fodder Beet (Beta vulgaris L. var. rapacea Koch.) by Using Potassium Salts. J Plant Pathol Microbiol 6: 315. doi:10.4172/2157-7471.1000315

\begin{tabular}{|c|c|c|c|c|c|}
\hline \multirow[b]{2}{*}{$\begin{array}{l}\text { Potassium } \\
\text { salts }\end{array}$} & \multirow[b]{2}{*}{$\begin{array}{c}\text { Concen. } \\
\text { (g/L) }\end{array}$} & \multicolumn{2}{|c|}{ Season 2013-2014 } & \multicolumn{2}{|c|}{ Season 2014-2015 } \\
\hline & & $\begin{array}{c}\% \\
\text { Damping- } \\
\text { off }\end{array}$ & $\begin{array}{c}\% \\
\text { Root rot/ } \\
\text { wilt }\end{array}$ & $\begin{array}{c}\% \\
\text { Damping-off }\end{array}$ & $\begin{array}{c}\% \\
\text { Root rot/wilt }\end{array}$ \\
\hline \multirow{4}{*}{$\mathrm{K}_{2} \mathrm{HPO}_{4}$} & 5 & 15.24 & 15.24 & 12.35 & 12.24 \\
\hline & 10 & 12.35 & 10.32 & 10.33 & 8.25 \\
\hline & 20 & 10.33 & 7.36 & 8.21 & 6.36 \\
\hline & Mean & 12.64 & 10.97 & 10.30 & 8.95 \\
\hline \multirow{4}{*}{$\mathrm{KHCO}_{3}$} & 5 & 25.36 & 19.35 & 24.14 & 18.52 \\
\hline & 10 & 20.55 & 15.34 & 18.25 & 12.36 \\
\hline & 20 & 14.86 & 16.25 & 13.24 & 14.96 \\
\hline & Mean & 20.26 & 16.98 & 18.54 & 15.28 \\
\hline \multirow{4}{*}{$\mathrm{K}_{2} \mathrm{SO}_{4}$} & 5 & 20.14 & 18.69 & 17.67 & 17.25 \\
\hline & 10 & 14.25 & 10.24 & 10.25 & 9.58 \\
\hline & 20 & 16.36 & 12.36 & 13.24 & 12.36 \\
\hline & Mean & 16.92 & 13.76 & 13.72 & 13.06 \\
\hline \multirow{4}{*}{$\mathrm{K}_{2} \mathrm{SiO}_{3}$} & 5 & 10.25 & 12.36 & 8.56 & 10.25 \\
\hline & 10 & 7.36 & 6.36 & 6.25 & 5.36 \\
\hline & 20 & 5.28 & 5.45 & 5.28 & 5.56 \\
\hline & Mean & 7.63 & 8.06 & 6.70 & 7.06 \\
\hline \multicolumn{2}{|c|}{ Control } & 35.26 & 25.36 & 30.25 & 26.35 \\
\hline \multicolumn{6}{|c|}{ LSD at 0.05 for: } \\
\hline \multicolumn{2}{|c|}{ Potassium salts $(A)=$} & 2.65 & 2.44 & 2.47 & 2.31 \\
\hline \multicolumn{2}{|c|}{ Concentrations $(\mathrm{B})=$} & 3.01 & 2.09 & 2.85 & 2.59 \\
\hline \multicolumn{2}{|c|}{ Pathogenic fungi $(\mathrm{C})=$} & 2.69 & 2.14 & 2.54 & 2.51 \\
\hline \multicolumn{2}{|c|}{ Interaction $(A \times B \times C)=$} & 7.48 & 6.51 & 7.01 & 6.78 \\
\hline
\end{tabular}

Table 4: Effect of fodder beet seeds treatment with potassium salts on dampingoff, root rot/wilt diseases during 2013/14 and 2014/15 growing seasons under field conditions.

$\mathrm{mM}$ in both growing seasons. $\mathrm{K}_{2} \mathrm{SiO}_{3}$ was more effective for controlling damping-off and root rot/wilt severity than the other tested potassium salts especially in case of higher concentration $(20 \mathrm{mM})$. While $\mathrm{K}_{2} \mathrm{SiO}_{3}$ at $20 \mathrm{mM}$ reduced damping off from 35.26 and $30.25 \%$ to $5.28,5.28 \%$ and reduced root rot/wilt from 25.36 and $26.35 \%$ in control to 5.45 and 5.36 in both growing seasons, respectivily. On the other hand, $\mathrm{KHCO}_{3}$ and $\mathrm{K}_{2} \mathrm{SO}_{4}$ were the lowest efficient in reducing damping-off and root rot/wilt in both growing seasons.

\section{The effect of potassium salts on fodder beet vigor and yield under field conditions}

Fodder beet seed soaking in any of these potassium salts at different concentrations were significantly submitted to various growths and yield parameters viz. root length, root diameters, fresh and dry weights, except $\%$ dry maters was no significant, compared with control during growing seasons 2013-14 and 2014-15 (Tables 5 and 6). The enhancement in growth and yield parameters were increased by increasing potassium salts concentration except $\mathrm{K}_{2} \mathrm{SO}_{4}$ at concentration $10 \mathrm{mM}$ was more effective for increasing plant growth and yield parameters than $20 \mathrm{mM}$ in both growing seasons. The applied treatment $\mathrm{K}_{2} \mathrm{SiO}_{3}$ achieved the highest increase in all the mentioned parameters over the other entire three potassium salts during both growing seasons. The average root length of untreated seeds (control) was 29.26 and $31.02 \mathrm{~cm} /$ root in control; it recorded 51.42 and 51.68 $\mathrm{cm} /$ root in $\mathrm{K}_{2} \mathrm{SiO}_{3}$ treatment at $20 \mathrm{mM}$ in both seasons, respectively. The diameter of root was 24.64 and $27.17 \mathrm{~cm}$ recorded in $\mathrm{K}_{2} \mathrm{SiO}_{3}$ at 20 $\mathrm{mM}$ compared to 12.33 and $13.45 \mathrm{~cm}$ in control. Also, fresh weight increased from 38.56 and 39.14 ton per fed. in control to 69.17 and 70.67 when applied $\mathrm{K}_{2} \mathrm{SiO}_{3}$ at $20 \mathrm{mM}$ treatment. The dry weight increased from 4.49 and 5.32 ton per fed. In control to 9.71 and 10.06 in treated with $\mathrm{K}_{2} \mathrm{SiO}_{3}$ at $20 \mathrm{mM}$. The percentage of dry mater increased from 11.46 and 12.42 in control to 14.03 and $14.24 \%$ in seed treated with $\mathrm{K}_{2} \mathrm{SiO}_{3}$ at $20 \mathrm{mM}$ in both growing seasons respectively. On the other hand, fodder seeds treated with $\mathrm{KHCO}_{3}$ recorded the lowest increased of various growths and yield parameters in both growing seasons.

\begin{tabular}{|c|c|c|c|c|c|c|}
\hline $\begin{array}{l}\text { Potassium } \\
\text { salts }\end{array}$ & $\begin{array}{c}\text { Concen. } \\
(\mathrm{gm} / \mathrm{L})\end{array}$ & $\begin{array}{l}\text { Root } \\
\text { length }\end{array}$ & $\begin{array}{l}\text { Root } \\
\text { Diam. }\end{array}$ & $\begin{array}{c}\text { Fresh } \\
\text { weight (ton/ } \\
\text { fed.) }\end{array}$ & $\begin{array}{c}\text { Dry weight } \\
\text { (ton/fed.) }\end{array}$ & $\begin{array}{c}\% \\
\text { Dry maters }\end{array}$ \\
\hline \multirow{4}{*}{$\mathrm{K}_{2} \mathrm{HPO}_{4}$} & 1 & 41.63 & 18.29 & 53.10 & 7.50 & 14.12 \\
\hline & 2 & 43.90 & 21.23 & 55.84 & 7.96 & 14.25 \\
\hline & 4 & 45.07 & 23.18 & 59.66 & 8.75 & 14.66 \\
\hline & Mean & 43.53 & 20.90 & 56.20 & 8.07 & 14.35 \\
\hline \multirow{4}{*}{$\mathrm{KHCO}_{3}$} & 1 & 33.96 & 14.23 & 43.26 & 6.02 & 13.92 \\
\hline & 2 & 35.42 & 15.49 & 44.96 & 6.3 & 14.01 \\
\hline & 4 & 36.58 & 17.01 & 46.32 & 6.59 & 14.23 \\
\hline & Mean & 35.32 & 15.58 & 44.85 & 6.30 & 14.05 \\
\hline \multirow{4}{*}{$\mathrm{K}_{2} \mathrm{SO}_{4}$} & 0.50 & 35.69 & 16.36 & 44.96 & 6.28 & 13.97 \\
\hline & 1.0 & 39.53 & 20.14 & 47.25 & 6.69 & 14.16 \\
\hline & 2.0 & 37.59 & 19.24 & 46.18 & 6.59 & 14.27 \\
\hline & Mean & 37.60 & 18.58 & 46.13 & 6.52 & 14.13 \\
\hline \multirow{4}{*}{$\mathrm{K}_{2} \mathrm{SiO}_{3}$} & 0.50 & 46.24 & 20.86 & 62.59 & 8.84 & 14.13 \\
\hline & 1.0 & 48.95 & 23.88 & 66.64 & 9.40 & 14.10 \\
\hline & 2.0 & 51.42 & 24.64 & 69.17 & 9.71 & 14.03 \\
\hline & Mean & 48.87 & 23.13 & 66.13 & 9.32 & 14.09 \\
\hline \multicolumn{2}{|c|}{ Control } & 29.26 & 12.33 & 38.56 & 4.49 & 11.46 \\
\hline \multicolumn{7}{|c|}{ LSD at 0.05 for: } \\
\hline \multicolumn{2}{|c|}{ Potassium salts $(A)=$} & 4.55 & 2.64 & 3.97 & 1.25 & ns \\
\hline \multicolumn{2}{|c|}{ Concentrations $(\mathrm{B})=$} & 3.96 & 2.55 & 3.47 & 1.19 & ns \\
\hline \multicolumn{2}{|c|}{ Interaction $(A \times B)=$} & 7.99 & 4.95 & 6.85 & 2.47 & ns \\
\hline
\end{tabular}

Table 5: Effect of fodder beet seeds treated with potassium salts on growth and yield parameters during 2013/14 growing season under field conditions.

\begin{tabular}{|c|c|c|c|c|c|c|}
\hline $\begin{array}{l}\text { Potassium } \\
\text { salts }\end{array}$ & $\begin{array}{c}\text { Concen. } \\
\text { (gm/L) }\end{array}$ & $\begin{array}{l}\text { Root } \\
\text { length }\end{array}$ & $\begin{array}{l}\text { Root } \\
\text { Diam. }\end{array}$ & $\begin{array}{c}\text { Fresh } \\
\text { weight (ton/ } \\
\text { fed.) }\end{array}$ & $\begin{array}{l}\text { Dry weight } \\
\text { (ton/fed.) }\end{array}$ & $\begin{array}{c}\% \\
\text { Dry } \\
\text { maters }\end{array}$ \\
\hline \multirow{4}{*}{$\mathrm{K}_{2} \mathrm{HPO}_{4}$} & 1 & 43.87 & 19.48 & 54.31 & 7.60 & 13.99 \\
\hline & 2 & 46.14 & 21.90 & 57.42 & 8.14 & 14.17 \\
\hline & 4 & 48.01 & 23.08 & 59.23 & 8.54 & 14.42 \\
\hline & Mean & 46.01 & 21.48 & 56.99 & 8.09 & 14.19 \\
\hline \multirow{4}{*}{$\mathrm{KHCO}_{3}$} & 1 & 35.49 & 15.69 & 44.23 & 6.23 & 14.09 \\
\hline & 2 & 37.25 & 16.58 & 46.32 & 6.49 & 14.01 \\
\hline & 4 & 39.85 & 17.02 & 47.25 & 6.69 & 14.16 \\
\hline & Mean & 37.53 & 16.43 & 45.93 & 6.47 & 14.09 \\
\hline \multirow{4}{*}{$\mathrm{K}_{2} \mathrm{SO}_{4}$} & 0.50 & 36.96 & 17.42 & 45.02 & 6.33 & 14.06 \\
\hline & 1.0 & 40.10 & 21.02 & 46.36 & 6.54 & 14.11 \\
\hline & 2.0 & 39.63 & 19.96 & 48.57 & 6.86 & 14.12 \\
\hline & Mean & 38.90 & 19.47 & 46.65 & 6.58 & 14.10 \\
\hline \multirow{4}{*}{$\mathrm{K}_{2} \mathrm{SiO}_{3}$} & 0.50 & 47.47 & 21.60 & 62.52 & 8.78 & 14.04 \\
\hline & 1.0 & 50.91 & 25.56 & 65.95 & 9.4 & 14.25 \\
\hline & 2.0 & 51.86 & 27.17 & 70.67 & 10.06 & 14.24 \\
\hline & Mean & 50.08 & 24.77 & 66.38 & 9.41 & 14.18 \\
\hline \multicolumn{2}{|c|}{ Control } & 31.02 & 13.45 & 39.14 & 5.32 & 12.42 \\
\hline \multicolumn{7}{|c|}{ LSD at 0.05 for: } \\
\hline \multicolumn{2}{|c|}{ Potassium salts $(A)=$} & 4.36 & 2.69 & 4.96 & 1.35 & ns \\
\hline \multicolumn{2}{|c|}{ Concentrations $(B)=$} & 3.45 & 2.58 & 3.64 & 1.15 & ns \\
\hline \multicolumn{2}{|c|}{ Interaction $(\mathrm{A} \times \mathrm{B})=$} & 7.56 & 4.59 & 8.02 & 2.48 & ns \\
\hline
\end{tabular}

Table 6: Effect of fodder beet seeds treated with potassium salts on growth and yield parameters during 2014/15 growing season under field conditions. 
Citation: Abdel-Monaim MF, Atwa MAM, Morsy KM (2015) Induce Systemic Resistance against Root Rot and Wilt Diseases in Fodder Beet (Beta vulgaris L. var. rapacea Koch.) by Using Potassium Salts. J Plant Pathol Microbiol 6: 315. doi:10.4172/2157-7471.1000315

\section{Biochemical changes associated with inducers PO, PPO, PAL and PAT activities}

The effect of potassium salts viz. $\mathrm{K}_{2} \mathrm{HPO}_{4}, \mathrm{KHCO} 3, \mathrm{~K}_{2} \mathrm{SO}_{4}$ and $\mathrm{K}_{2} \mathrm{SiO}_{3}$ as inducer chemicals on the activities of $\mathrm{PO}, \mathrm{PPO}, \mathrm{PAL}$ and TAL of the fodder beet plants grown in soil infested with R. solani, F. solani, F. oxysporum separately was studied. The data are presented in Figures 2-5 show that all tested potassium salts increased the activity of PO, PPO, PAL and TAL in the fodder beet compared with untreated plants (control). $\mathrm{K}_{2} \mathrm{SiO}_{3}$ at $20 \mathrm{mM}$ showed the highest level of all oxidative enzymes activity followed by $\mathrm{K}_{2} \mathrm{HPO}_{4}$ at $20 \mathrm{mM}$ and $\mathrm{K}_{2} \mathrm{SO}_{4}$ at $20 \mathrm{mM}$. Whereas, the least enzymes activity was recorded with $\mathrm{KHCO}_{3}$ at 10 $\mathrm{mM}$. On the other hand, fodder beet plants inoculated with $R$. solani were recorded the highly level of PO, PAL, TAL enzymes more than plants inoculated with F. solani or F. oxysporum either in treated and untreated fodder beet plants. While, PPO enzyme was more activity in case of fodder plants inoculated with $F$. oxysporum than the other tested fungi.

\section{Effect of potassium salts on total phenols content}

Data present in Figure 6 indicate that total phenolic compounds were higher in fodder beet plants treated with all the tested potassium

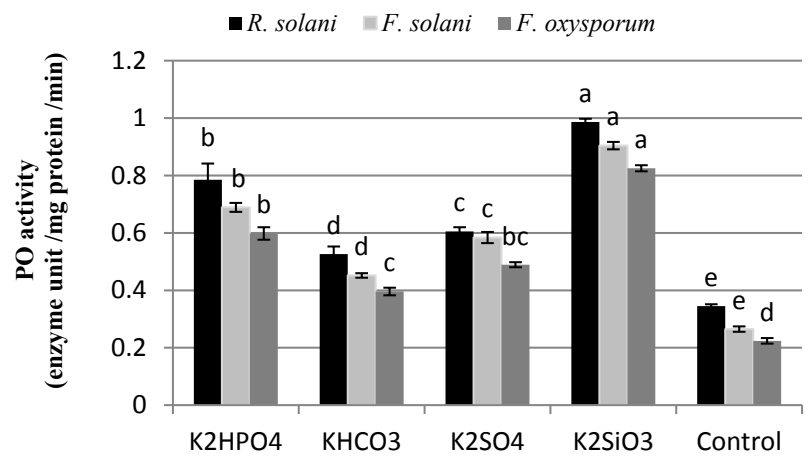

Treatments

Figure 2: Effect of potassium salts on peroxidase activity $(\mathrm{PO})$ in inoculated fodder beet plants. Mean \pm SDs for nine plants per treatment are shown. Different letters indicate significant differences between treatments according to LSD test $(P \leq 0.05)$.

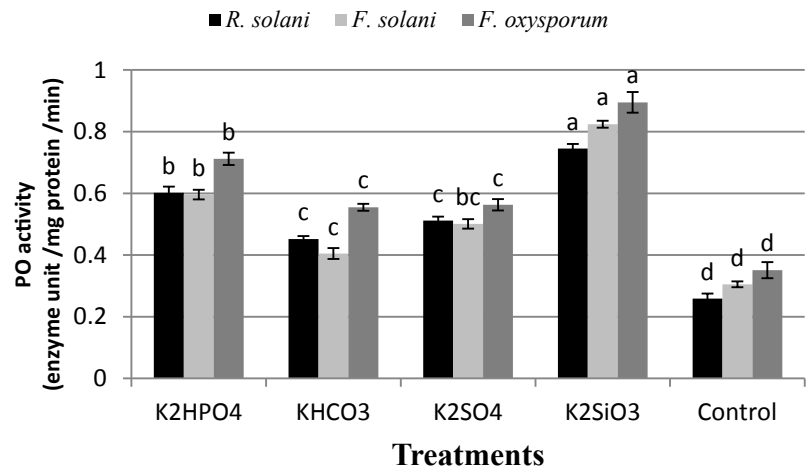

Figure 3: Effect of potassium salts on polyphenol oxidase activity (PPO) in inoculated fodder beet plants. Mean \pm SDs for nine plants per treatment are shown. Different letters indicate significant differences between treatments according to LSD test $(P \leq 0.05)$.

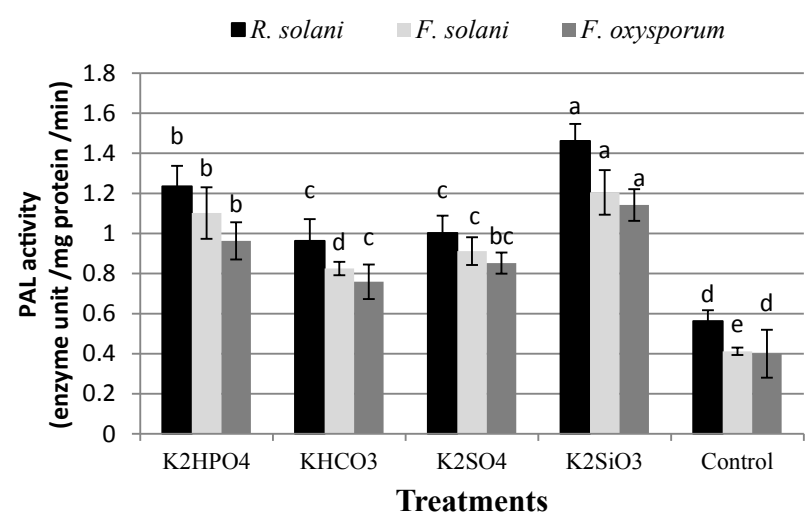

Figure 4: Effect of potassium salts on phenylalanine ammonia lyase activity (PAL) in inoculated fodder beet plants. Mean \pm SDs for nine plants per treatment are shown. Different letters indicate significant differences between treatments according to LSD test $(P \leq 0.05)$.

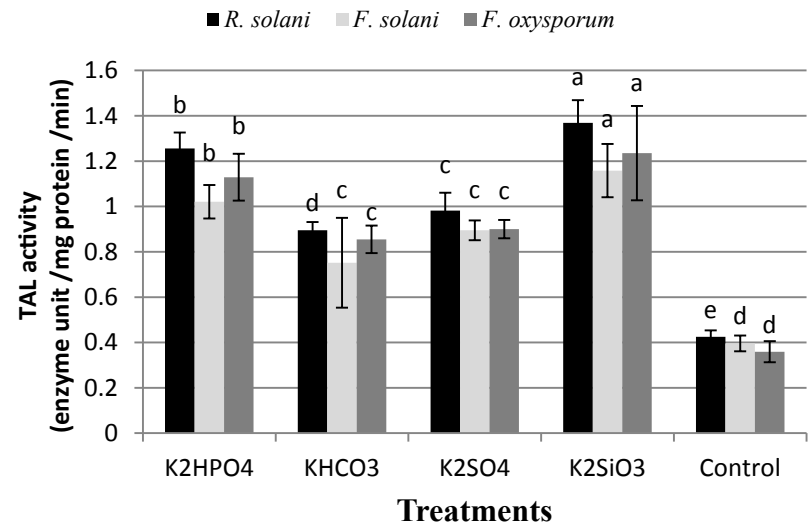

Figure 5: Effect of potassium salts on tyrosine ammonia lyase activity (TAL) in inoculated fodder beet plants. Mean \pm SDs for nine plants per treatment are shown. Different letters indicate significant differences between treatments according to LSD test $(P \leq 0.05)$.

salts than those of untreated infected control. The higher total phenolic contents were recorded plants treated with $\mathrm{K}_{2} \mathrm{SiO}_{3}$ at $20 \mathrm{mM}$ followed by $\mathrm{K}_{2} \mathrm{HPO}_{4}$ at $20 \mathrm{mM}$. While, the lowest content of total phenolic compounds was recorded in plants treated with $\mathrm{K}_{2} \mathrm{SO}_{4}$ at $10 \mathrm{mM}$. on the other hand, fodder beet plants inoculated with $R$. solani gave highly content of phenolic compounds than plants inoculated with $F$. solani or F. oxysporum either in treated plants with potassium salts or untreated.

\section{Discussion}

Plant diseases caused by soil-borne plant pathogens considered the major problems in agricultural production throughout the world, reducing yield and quality of crops. Plant pathogens have caused an almost $20 \%$ reduction in the principal food and cash crops worldwide $[4,22]$.

Control of soil borne pathogens with chemicals is difficult because of their ecological behavior, their extremely broad host range and the high survival rate of resistant forms such as sclerotia and chlamediospores under different environmental conditions [23]. In recent years, public demands to reduce pesticide use, stimulated by greater awareness of environmental and health issues as well as the development of fungicide resistant strains of pathogens, have created 


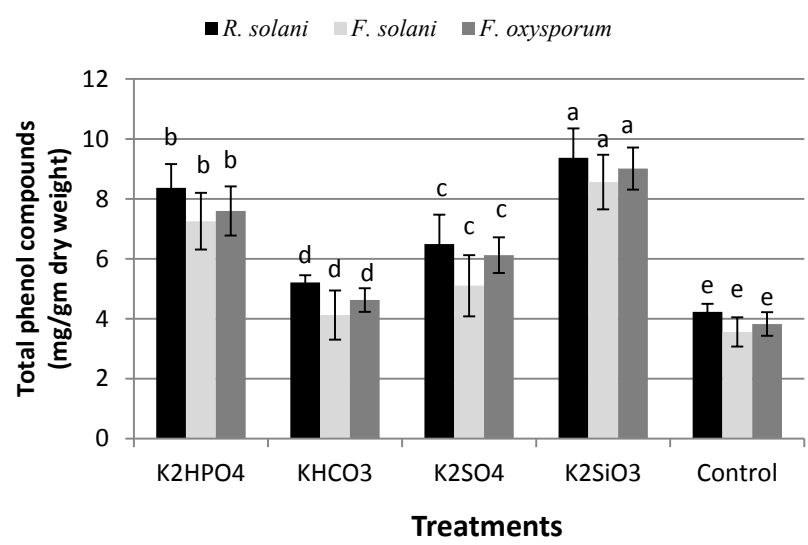

Figure 6: Effect of potassium salts on total phenol content (TPC) in inoculated fodder beet plants. Mean \pm SDs for nine plants per treatment are shown. Different letters indicate significant differences between treatments according to LSD test $(P \leq 0.05)$.

the need to find alternatives to pesticides. Natural substances such as some potassium salts may be used to achieve this aim. The main advantages of using potassium salts compared with fungicides include their relatively low mammalian toxicity, a broad spectrum of modes of action and relatively low cost [24]. They also have wide spectrum antimicrobial properties. They have been shown to be effective growth inhibitors of some soil borne fungal pathogens $[25,26]$.

In the present study, it was planning to investigate the possibility of minimizing the infection with damping-off, root rot and wilt diseases caused by R. solani, F. solani, F. oxysporum of fodder beet using some potassium salts viz. $\mathrm{K}_{2} \mathrm{HPO}_{4}, \mathrm{KHCO}_{3}, \mathrm{~K}_{2} \mathrm{SO}_{4}$ and $\mathrm{K}_{2} \mathrm{SiO}_{3}$ at $5,10,20 \mathrm{mM}$ as resistance inducer. The obtained data revealed that all potassium salts caused significantly suppressed redial growth of the tested pathogenic fungi in vitro. The growth suppression was increased by increasing of potassium salts concentrations and $\mathrm{KHCO}_{3}$ showed superior higher inhibitory effect on redial growth of the tested pathogenic fungi especially at higher concentration $(20 \mathrm{mM})$. Also, all tested potassium salts significantly reduced damping-off, root rot and wilt diseases incidence either under artificial infection in greenhouse of natural infection in field, compared with the control treatment. In general, $\mathrm{K}_{2} \mathrm{SiO}_{3}$ at the high concentration $(20 \mathrm{mM})$ was more efficient in reducing disease incidence followed by $\mathrm{K}_{2} \mathrm{HPO}_{4}$ at $20 \mathrm{mM}$. Moreover, $\mathrm{K}_{2} \mathrm{SO}_{3}$ and $\mathrm{KHCO}_{3}$ was the lowest affected one by the investigated diseases.

Also, under field conditions, all potassium salts improved growth and yield components of fodder beet in both growing seasons. The applied treatment $\mathrm{K}_{2} \mathrm{SiO}_{3}$ achieved the highest increase in all the mentioned parameters (root length, root diameters, fresh and dry weights and $\%$ dry maters) over the other entire three potassium salts during both growing seasons.

On the other hand, potassium salts due to many biochemical changes in fodder beet plants either in inoculated or un-inoculated plants with tested pathogens. While, all tested potassium salts increased activity of peroxidase, polyphenol oxidase, phenyalalanine ammonia lyase and tyrosine ammonia lyase as well as total phenolic compounds. $\mathrm{K}_{2} \mathrm{SiO}_{3}$ was recorded the highest activity of all enzymes and total phenolic compounds followed by $\mathrm{K}_{2} \mathrm{HPO}_{4}$, while $\mathrm{KHCO}_{3}$ and $\mathrm{K}_{2} \mathrm{SO}_{4}$ recorded the lowest ones in this respect.
Many investigations reported the use of potassium salts as a chemical agent for induction of plant resistance [27,28]. Furthermore, there has been considerable interest in the use of potassium bicarbonate and potassium phosphate, potassium sulfate and potassium silicate for controlling various fungal diseases in plants [29-32]

Potassium is a mobile element with multiple functions in the plant. It acts as a counter-ion for anion transport, regulates stomatal aperture and the water potential of plant cells, affects cell wall plasticity, as well as other roles [33]. It promotes wound healing and decreases frost injury [34]. Potassium deficiency has been found to be linked to diseases in a number of temperate crops [34] and a high $\mathrm{K}$ supply can improve resistance of plants to fungal and bacterial pathogens $[35,36]$. The mechanism of resistance in some disease-resistant genotypes might be related to a greater efficiency in $\mathrm{K}$ uptake [37]. The potassium bicarbonate causes the collapse of hyphal walls and shrinkage of conidia, [38].

In general, potassium application improves plant health and vigour, making infection less likely or enabling a quick recover [39]. Potassium probably exerts its greatest effects on disease through specific metabolic functions that alter compatibility relationships of the host-parasite environment and increases the production of disease inhibitory compounds, such as phenols, phytoalexins and auxins around infection sites of resistant plants $[40,41]$.

In conclusion, the present study provides further evidence that may facilitate applying simple non-toxic chemicals as potassium salts for controlling damping-off, root rot and wilt diseases in fodder beet. Their low cost, low toxicity to the man and environmental pollution make them ideal seed soaking for disease control under field conditions and increased root yield and dry mater.

\section{References}

1. DAF (Department of Agriculture and Food) (1998) Root, fodder crop, pulse and oilseed varieties. Irish recommended list. Government Stationary Office, Dublin, p. 17.

2. Turk M (2010) Effects of fertilization on root yield and quality of fodder beet (Beta vulgaris var. crassa Mansf.). Bulgarian Journal of Agricultural Science 16: $212-219$.

3. Abdel -Naby ZM, Shafie WWM, Sallam AM, El-Nahrawy SM, Abdel-Ghawad MF (2014) Evaluation of seven fodder beet genotypes under different Egyptian ecological conditions using regression, cluster models and variance measures of stability. Int J Curr Microbiol App Sci 3: 1086-1102.

4. Oerke EC, Dehne HW, Schonbeck F, Weber A (1994) Crop Production and Crop Protection - Estimated Losses in Major Food and Cash Crops, Elsevier Science, Amsterdam, pp 808.

5. El-Mohamedy RSR, Abdel-Kader MM, Abd-El-Kareem F, El-Mougy NS (2013) Essential oils, inorganic acids and potassium salts as control measures against the growth of tomato root rot pathogens in vitro. Journal of Agricultural Technology 9: 1507-1520.

6. De Waard A, Georgopoulos SG, Hollomon DW, Ishii H, Leroux P, et al (1993) Chemical control of plant diseases: problems and prospects. Ann Rev Phytopathol 31: 403-423.

7. Booth C (1985) The genus Fusarium. Surrey: Commonwealth Mycological Institute.

8. Barnett HL, Hunter BB (1986) Illustrated Genera of Imperfect Fungi. 4 th Ed., Macmillan Publishing Co., New York.

9. Abo-Elyousr KAM, Mohammed H (2009) Biological Control of Fusarium Wilt in Tomato by Plant Growth-Promoting Yeasts and Rhizobacteria. The Plant Pathology J 25: 199-204.

10. Abdou El-S, Abd-Alla HM, Galal AA (2001) Survey of sesame root rot/wilt disease in Minia and their possible control by ascorbic and salicylic acids. Assuit J Agric Sci 32: 135-152. 
Citation: Abdel-Monaim MF, Atwa MAM, Morsy KM (2015) Induce Systemic Resistance against Root Rot and Wilt Diseases in Fodder Beet (Beta vulgaris L. var. rapacea Koch.) by Using Potassium Salts. J Plant Pathol Microbiol 6: 315. doi:10.4172/2157-7471.1000315

11. Liu L, Kloepper JW, Tuzun S (1995) Introduction of systemic resistance in cucumber against fusarium wilt by plant growth-promoting rhizobacteria. Phytopathol 85: 695-698.

12. Somda I, Leth V, Sereme P (2007) Antifungal effect of Cymbopogon citratus, Eucalyptus camaldulensis and Azadirachta indica oil extracts on sorghum seed-borne fungi. Asian J Plant Sci 6:1182-1189

13. Biles CL, Martyn RD (1993) Peroxidase, polyphenoloxidase, and shikimate dehydrogenase isozymes in relation to tissue type, maturity and pathogen induction of watermelon seedlings. Plant Physiol Biochem 31: 499-506.

14. Hammerschmidt R, Nuckles EM, Ku J (1982) Association of enhanced peroxidase activity with induced systemic resistance of cucumber to Colletotrichum lagenarium. Physiol Plant Pathol 20: 73-82.

15. Urbanek H, Kuzniak-Gebarowska E, Herka H (1991) Elicitation of defense responses in bean leaves by Botrytis cinerea polygalacturonase. Acta Physiol Plant13: 43-50

16. Gauillard F, Richard-Forget F, Nicolas J (1993) New spectrophotometric assay for polyphenol oxidase activity. Anal Biochem 215: 59-65.

17. Cavalcanti FR, Resende ML, Carvalho CP, Silveira JA, Oliveira JT (2007) An aqueous suspension of Crinipellis perniciosa mycelium activates tomato defense responses against Xanthomonas vesicatoria. Crop Prot 6: 729-38.

18. Bradford MM (1976) A rapid and sensitive method for the quantitation of microgram quantities of protein utilizing the principle of protein-dye binding. Anal Biochem 72: 248-254.

19. Saikia R, Yadav M, Varghese S, Singh BP, Gogoi DK, et al. (2006) Role of riboflavin in induced resistance against Fusarium wilt and charcoal rot diseases of chickpea. Plant Pathol J 22: 339-47.

20. MSTAT-C (1991) A Software Program for the Design, Management and Analysis of Agronomic Research Experiments. Michigan State University, pp. 400 .

21. Gomez KA, Gomez AA (1984) Statistical procedures for agricultural research New York: Wiley Interscience Publication p. 678.

22. Villajuan-Abgona R, Kageyama K, Hyakumachi M (1996) Biological control of Rhizoctonia damping-off of cucumber by non-pathogenic binucleate Rhizoctonia. Euro J Plant Pathol 102: 227- 235.

23. Yangui T, Rhouma A, Triki MA, Gargouri K, Bouzid J (2008) Control of damping-off caused by Rhizoctonia solani and Fusarium solani using olive mill waste water and some of its indigenous bacterial strains. Crop Protection 27: 189-197.

24. Olivier C, Halseth DE, Mizubuti SG, Loria R (1998) Post-harvest application of organic and inorganic salts for suppression of silver scurf on potato tubers. Plant Dis 82: 213-217.

25. Arslan U, Kadir I, Vardar C, Karabulut OA (2009) Evaluation of antifungal activity of food additives against soilborne phytopathogenic fungi. World $J$ Microbiol Biotechnol 25: 537-543.

26. Ordonez C, Alarcón A, Ferrera R, Hernández LV (2009) In vitro antifungal effects of potassium bicarbonate on Trichoderma sp. and Sclerotinia sclerotiorum. Mycoscience 50: 380-387.

27. Stromberge A, Brishammar S (1991) Induction of systemic resistance in potato (Solanum tuberosum L.) plants to late blight by local treatment with Phytophthora infestans, Phytophthora cryptogea or dipotassium phosphate. Potato Res 34: 219-225

28. Yurina TP, Karavaev VA, Solntsev MK (1993) Characteristics of metabolism in two cucumber cultivars with different resistance to powdery mildew. Russian Plant Physiol 40: 197-202.

29. Karabulut OA, Smilanick JL, Gabler FM, Mansour M, Droby S (2003) Nearharvest applications of Metschnikowia fructicola, ethanol, and sodium bicarbonate to control postharvest diseases of grape in central California. Plant Dis 87: 1384-1389.

30. Smilanick JL, Mansour MF, Sorenson D (2006) Pre- and postharvest treatments to control green mold of citrus fruit during ethylene degreening. Plant Dis 90 : 89-96.

31. Ragab MMM, Ashour AMA, Abdel-Kader MM, El-Mohamady R, Abdel-Aziz A (2012) In vitro evaluation of some fungicides alternatives against Fusarium oxysporum the causal of wilt disease of pepper (Capsicum annum L.). International $\mathrm{J}$ of Agric and Forestry 2: 70-77.

32. Safari S, Soleimani MJ, Zafari D (2012) Effects of silicon pretreatment on the activities of defense-related enzymes in cucumber inoculated with Fusarium oxysporum. Adv Environ Biol 6: 4001-4007.

33. Rice RW (2007) "The Physiological Role of Minerals in Plants." In Minera Nutrition and Plant Disease, edited by L. E. Datnoff, Wade H. Elmer and D. M. Huber, 9-30. St. Paul, Minn: American Phytopathological Society, 2007.

34. Palti J (1981) Cultural Practices and Infectious Crop Diseases. Vol. 9. New York: Springer-Verlag.

35. Marschner H (1995) Mineral nutrition of higher plants, 2ndedn. Academic London.

36. Perrenoud S (1990) Potassium and Plant Health. IPI Research Topics No. 3 2nd Ed. International Potash Institute, Bern, Switzerland.

37. Prabhu M, Veeraragavathatham D, Srinivasa K (2003) Effect of nitrogen and phosphorous on growth and yield of brinjal. South-Indian-Hort 51: 152-156

38. Ziv O, Zitter TA (1992) Effects of bicarbonates and film-forming polymers on cucurbit foliar diseases. Plant Dis 76: 513-517.

39. Perrenoud S (1993) Fertilizing for High Yield Potato. IPI Bulletin 8. 2nded International Potash Institute, Basel, Switzerland.

40. Legrand M, Kauffmann S, Geoffroy P, Fritig B (1987) Biological function of pathogenesis-related proteins: Four tobacco pathogenesis-related proteins are chitinases. Proc Natl Acad Sci USA 84: 6750-6754.

41. Abd-El-Kareem F, El-Mougy Nehal S, El-Gamal NG, Fotouh YO (2004) Induction of resistance in squash plants against powdery mildew and Alternaria leaf spot diseases using chemical inducers as protective or therapeutic treatments. Egypt J Phytopathol 32: 65-76. 